Journal Universitas Muhammadiyah Gresik Engineering, Social Science, and Health International Conference (UMGESHIC)

UMGCINMATIC : $1^{\text {st }}$ Rethinking Education during Covid-19 Era: Challange and Innovation

\title{
THE EFFECT OF LEVERAGE, PROFITABILITY, COMPANY SIZE AND REPUTATION OF KAP ON THE TIMELINESS OF FINANCIAL STATEMENT SUBMISSION
}

\author{
Author \\ Ifanda Rosalina ${ }^{1}$, Syaiful ${ }^{2}$ \\ 1,2 University of Muhammadiyah Gresik \\ ifandarosalina1@gmail.com ${ }^{1}$, syaiful@umg.ac.id ${ }^{2}$
}

\begin{abstract}
The purpose of this study is to examine whether or not the variables of leverage, profitablitas, company size and reputation of public accounting firm influence timely submission of financial reports. The object of this research is manufacturing companies listed on the Indonesia Stock Exchange (IDX) for the period 2018 to 2020. The research data was collected by using documentation technique on the sample company's financial statement items. By using purposive sampling, the final sample size is 139 companies. The research hypothesis was tested using logistic regression analysis. The result oh hypothesis testing concluded that leverage has no effect on the timeliness of submitting financial statements, profitabilitas has no effect on the timeliness of submitting financial statements, company size has a effect on the timeliness of submitting financial statements, the reputation of a public accounting firm has no effect on the timeliness of submitting financial statements.
\end{abstract}

Keywords: leverage, profitability, company size, reputation of public accounting firm, timely submission of financial reports 


\section{INTRODUCTION}

Financial statements are records that contain information about the company's finances that can be used as an overview of the company's performance. Financial statements as a form of communication from the company's internal parties in providing important information about the company's performance to the company's external parties. The main purpose of financial statements is to provide useful information for decision making, this is management's accountability to all elements of activities within nurmiati company, (2016). The timely delivery of financial statements is very important for the company because when the report is delivered quickly and appropriately, the information contained in the report will contain the benefits used by the users of the financial statements at the time of decision making. Conversely, when the companyhas a delayin delivering then what happens is the quality of the decisions taken by investors will be reduced.

But the reality that occurs is that there are companies or issuers in Indonesia that still exceed the deadline set in submitting financial statements to the Financial Services Authority (OJK) and to users of financial statements.. Law No. 21 of 2011 concerning the Financial Services Authority has regulated the timing of the submission of financial statements for all companies listed on the IDX. The contents of the Act state that the entire company is obliged to publish its report periodically to the OJK (Financial Services Authority) and must make it public. Inthe annex of the decree of thechairman of OJK (Financial Services Authority) Number: Kep-36 / PM / 2011 has been mentioned that the company's annual financial statements that have been audited must be submitted to Otoritas Jasa Keuagan (OJK) at the latest, namely in late March or 90 days after the date of the annual financial report.

Astuti (2019) provided the results of his research that the leverage had no effect on the timeliness of the delivery of financial statements. The results of Astuti's research (2019) on leverage variables are comparable to those studied by Firdaus, Amin, \& Junaidi (2018) that leverage variables turned out to have no effect. While different in his research Nurmiati (2016) which shows that there is an influence on the timeliness of the delivery of financial statements, namely leveragevariables. This indicates if there is a company whose high level of leverageis usually not on time in financial reporting because the company has a high level of financial risk as well so that the audit process becomes longer and 
affects the time of delivery of its financial statements. In addition Suprapti (2015) also examined and proved that profitability variables turned out to have a significant influence with the timeliness of financial reporting. The results of the study were also proven by Sanjaya \& Wirawati (2016) and Jaori, Mario Kristopp (2018) in a case study in the IDX period 2014-2016 with results if profitability variables have a positive and significant relationship with the timeliness of delivery of the company's financial statements. But unlike the research of Rinawati (2008), which showed that profitability variables had no influence with the timeliness of the delivery of financial statements.

Then Kuswanto \& Sodikin (2013), proved in his research that there is a reputation of KAP as an independent variable that has no significant effect with the timeliness of financial reporting. But in Astuti's research (2019),kap's reputation variables have an influence on the timeliness of financial reporting. In his research mentioned if a reputable auditor will have a better quality audit results and certainly right at the time of submission of his report.

This means, the use of auditors who have a qualified KAP reputation can have an effect with the time of submission of reports appropriately.

From the background description above there are various differences in results that are not consistent, so researchers are interested in conducting research. Here is a problem formula seen from the background above:

1. Does leverage affect the timeliness of the delivery of financial statements?

2. Does profitability affect the timeliness of the delivery of financial statements?

3. Does the size of the company affect the timeliness of the delivery of financial statements?

4. Does kap's reputation affect the timeliness of the delivery of financial statements?

\section{METHODS}

\section{Population and Research Sample}

The population used in this study is all manufacturing companies amounting to 198 companies that issue annual financial statements on the Indonesia Stock Exchange (IDX) for the period 2018-2020. Purposive sampling method becomes a method that will be used in the study this time because the method is based on the selection of certain criteria to obtain relevant samples in accordance with 
UMGCINMATIC : $1^{\text {st }}$ Rethinking Education during Covid-19 Era: Challange and Innovation Volume 1 No 2

the purpose of the researchUt are some of the criteria that will be used for sampling in this study:

1. Manufacturing companies that have been registered with idx for the period 2018-2020.

2. Report annual reports in rupiah

3. Publish annual audited financial statements consecutively for the period 2018 -2020 .

\section{Types and Sources of Data}

This study uses this type of data in the form of secondary data, where the data is obtained from the annual financial statements of manufacturing companies listed on the Indonesia Stock Exchange (IDX) for the period 2018 to 2020. The source of this research data was found on the official website of the Indonesia Stock Exchange (IDX) which is www.idx.co.id in 2018 to 2020.

\section{Definition of Operation and Variables}

\section{Dependent Variable $(Y)$}

The dependent (bound) variable in this study is the timeliness of the delivery of financial statements. Based on the statement attached in the decree by the chairman of OJK (Financial Services Authority) Number: Kep-36 / PM / 2011 that the company's annual financial statements recorded that have been carried out the audit process must be submitted to the Financial Services Authority (OJK) maximum at the end of the third month of March or if calculated based on the day is 90 days, which is calculated from the closing date of the company's book.

These dependent variables are measured by looking at the length of days it takes to obtain audited financial statements. The calculation of the length of time is from the start of the company's book closing date or the end of the year which is December 31 until the date listed in the audit report. The company is said to be on time if its financial statements are submitted $<90$ days will get a score of 1 , instead the company is said not to be on time if its financial statements are submitted $>90$ days will get a score of 0 . 
Independent Variables (X)

\section{Leverage}

Leverage is a ratio that shows the level of activity of a company financed from the use of debt. The existence of a high corporate risk identifies that the company is experiencing financial difficulties. The company's financial difficulties will have a bad impact on the financial condition in public, if the company's leverage is high then the level of debt owned by the company is also high and does not rule out the possibility of the company to pay debts to creditors is higher.

The company will improve its leverage level first before its financial statements are delivered. This, will make the company's management delay its financial reporting and will cause bad news for investors or interested parties to the financial statements, because logically if the company has more debt, then not many investors will invest in the company because the company's money is considered too small and the dividend generated for investors is also less than companies that do not. He has a lot of cashmere debt, (2015:92).

In this study, the indicator used to regulate leverage levels was the Debt to Equity Ratio (DER). This ratio indicates the amount of assets of the company financed by the amount of debt. The higher the company has this ratio indicates the greater the amount of loans used in the financing of assets used by the company to obtain profits.

This variable is measured using the formula:

DER $=$ Total Liabilities : Total Equity

\section{Profitability}

Profitability becomes one of the gauges of the level of profit or profit obtained by a company for its operational activities. If the company has a high ability to profit then what happens in its management is the higher the effectiveness of santoso management (2010: 96).

Shareholders can use profitabillity as information to find out how much profit is actually received in dividends. Profitability is also used by investors to estimate how much the change in value of the shares owned. Creditors can also use profitability to measure the ability to pay principal and interest on Cashmere 
loans (2015:122).

In this case profitability becomes an important thing to note for report users to facilitate in making investment decisions, so that companies that have a high profitability ratio will have the desire to deliver their financial statements in a timely manner to provide good signals or good information to interested parties on the financial statements. This study uses indicators in the form of Return On Asset (ROA) to measure the level of profitability of a company.

The formula used is:

ROA = Net Income $:$ Total Assets

Company Size

According to Brigham and Houston (2012: 54) the size of a company is a scale of a company that is classified based on the size of the company judging by the total assets, log size, stock market value and others. Investors will tend to highlight companies that are large rather than small companies so that large companies will provide information in the form of financial statements in a timely manner to users of financial statements.

This study used the proxy size of the natural log of the total assets. The use of natural logs $(L n)$ in this study with the intention to reduce the existence of large data fluctuations, because if the total value of assets is directly entered then the value will be very large. Therefore, the large value can be simplified without changing the proportion of the actual original value by using the natural log.

The measurement formula is:

Company Size $=\operatorname{Ln}$ (Total Assets)

\section{Kap Reputation}

Kap's reputation is the achievement and public trust held by auditors on behalf of the auditors. Kap's reputation has a close relationship with its auditors because each auditor has a difference in quality and independence between KAP big four or non big four Rudyawan and Badera (2009). Auditors who have a reputation for KAP by being affiliated with the KAP big four tend to have much better quality, because kap big four has auditors with characteristics related to quality such as training, and international recognition. This KAP reputation variable is measured on a ordinal scale using the following scores:

Score 5 = Companies affiliated with KAP Deloitte Touche Thomatsu. Score 4 = Companies affiliated with KAP Ernst and Young. 
UMGCINMATIC : $1^{\text {st }}$ Rethinking Education during Covid-19 Era: Challange and Innovation Volume 1 No 2

Score 3 = Companies affiliated with KAP KPMG (Klynveld Peat) Maewick Goerdeler).

Score 2 = Companies affiliated with KAP Price Waterhouse Coopers.

Score 1 = Companies affiliated with KAP Non Big Four

\section{DISCUSSION}

\subsection{Descriptive Statistics}

From the results of descriptive statistical tests that have been conducted in this study, obtained results as presented in the table below:

Table 4.1

Descriptive Statistical Test Results

\begin{tabular}{|c|c|c|c|c|c|}
\hline \multicolumn{6}{|c|}{ Descriptive Satistics } \\
\hline & $\mathrm{k}$ & Menimum & Mainum & Mean & Sd Deriation \\
\hline$D \mathbb{R}$ & 413 & $-2,21$ & 114,29 & 1,5323 & 5,9568 \\
\hline POA & 213 & $-1,3 \pi$ & 8,30 & .0655 & 23069 \\
\hline STE & 417 & $x, 64$ & 33,49 & $28,4 \pi 9$ & 1,65516 \\
\hline Valu (istuise) & 417 & & & & \\
\hline
\end{tabular}

Source: SPSS 22, Data processed by researchers (2021)

From table 4.1 above is known asil descriptive statistical analysis, the number of samples $(\mathrm{N})$ used in this study is 417 companies in idx with a research period of 3 years, namely during 2018-2020. The bound variables used in the study were the timeliness of the delivery of financial statements while leverage, profitability, company size and KAP's reputation as a free variable. The results of descriptive analysis for each variable can be explained as follows:

1. Leverage (X1)

The leverage variable as measured by the Debt to Equity Ratio (DER) has a minimum value of -2.21 and a maximum value of 114.29 . The average value is 1.5323 with a standard deviation of 5.94586. During the research period, the minimum leverage value was held by companies with BIMA issuer codes in 2018. The maximum value is owned by a company with the issuer code MYTX in 2020.

2. Profitability (X2)

Profitability variables are measured by Return on Assets (ROA). Profitability has a minimum value of -1.37 and a maximum value of 8.30 . The average value is 0.0575 with a standard deviation of 0.43069 . During the research period, the minimum profitability value was owned by companies with the issuer code MGNA in 2019. The maximum value is also owned by companies with 
the issuer code MGNA in 2020.

3. Company Size (X3)

Company size variables are measured by natural logs of assets. The size of the company has a minimum value of 22.64 and a maximum value of 33.49. The average value is 28.4119 with a standard deviation of 1.65516 . During the research period, the minimum value of the size of the company was owned by the company with the issuer code MGNA in 2020. The maximum value is owned by companies with the issuer code ASII in 2019.

Table 4.2

KWPLK Frequency Distribution Statistical Test Results

KWPLK

\begin{tabular}{|c|c|c|c|c|}
\hline & Frequency & Percent & Valid Percent & $\begin{array}{l}\text { Cumulative } \\
\text { Percent }\end{array}$ \\
\hline Valid & 123 & 29,5 & 29,5 & 29,5 \\
\hline 1 & 294 & 70,5 & 70,5 & 100,0 \\
\hline Total & 417 & 100,0 & 100,0 & \\
\hline
\end{tabular}

Source: SPSS 22, Data processed by researchers (2021)

Table 4.2 above is the statistical result of frequency distribution on the timeliness variable of the delivery of financial statements. Companies that have a score of 0 are not on time in delivering their financial statements, the table above shows there are 123 observations or $29.5 \%$. While companies that have a score of 1 are companies that are on time in delivering their financial statements, the table above shows there are 294 observations or $70.5 \%$.

Table 4.3

Kap Reputation Frequency Distribution Statistical Test Results

\begin{tabular}{|c|c|c|c|c|}
\hline & Frequency & Perosats & Wast perost & $\begin{array}{l}\text { Cumbersive } \\
\text { Peroost }\end{array}$ \\
\hline valid 1 & 234 & 70,5 & 70.5 & 70,5 \\
\hline $\begin{array}{l}2 \\
3\end{array}$ & $\begin{array}{l}{ }^{24} \\
{ }_{21}\end{array}$ & $\begin{array}{l}5,8 \\
50\end{array}$ & 50 & $\begin{array}{l}3 ., 3 \\
81,3\end{array}$ \\
\hline 4 & 7 & 170 & 17,0 & 9 \\
\hline 5 & 7 & 1,7 & 1,7 & 1000 \\
\hline Tosad & 417 & 1000 & 1000 & \\
\hline
\end{tabular}

Source: SPSS 22, Data processed by researchers (2021)

Table 4.3 above is a statistical result of frequency distribution on the KAP reputation variable. Score 1 is a company that uses kap non big four as many as 294 observations or $70.5 \%$. Score 2 is a company that uses KAP PWC as many 
UMGCINMATIC : $1^{\text {st }}$ Rethinking Education during Covid-19 Era: Challange and Innovation Volume 1 No 2

as 24 observations or $5.8 \%$. Score 3 is a company that uses KAP KPMG as many as 21 observations or $5.0 \%$. Score 4 is a company that uses KAP EY as many as 71 observations or $17.0 \%$. Score 5 is a company that uses KAP DTT as much as 7 observations or $1.7 \%$.

\subsection{Assessing Model Feasibility (Goodness of Fit Test)}

The feasibility of the regression model is tested using Hosmer and Lemeshow's Goodness of Fit Test which serves to find out if the data sample obtained is in accordance with the regression model used. The test was measured by looking at the value of Chi-square, where the significance level used was 0.05 . If the statistical value of Goodness of Fit Test Hosmer and Lemeshow is greater than 0.05 , then the hypothesis is accepted. This indicates the conformity between the model and the observed value so that it is said to be appropriate. The test results can be seen in the following table:

Table 4.4

Hosmer and Lemeshow's Goodness Of Fit Test Results

Hosmer and Lemeshow Test
\begin{tabular}{|l|r|r|r|}
\hline Step & Chisquare & df & Sig. \\
\hline 1 & 8,594 & & 8 \\
\hline
\end{tabular}

Source: SPSS 22, Data processed by researchers (2021)

Based on table 4.4 results of the Hosmer and Goodness of Fit Test Lemeshow showed a Chi-Square value of 8,594 with a significance level of 0.378 . This suggests that the significance level of 0.378 is greater than 0.05 so it can be said that the regression model in this study is acceptable because the model corresponds to the observed value.

\subsection{Assess the Overall Model}

Overall model testing serves to find out whether the hypothesized model matches or not with the data. The test is done by comparing the difference in the value of -2 of the initial likehood log (Block number $=0$ ) with the value of -2 of the final likehood log (Block number $=1$ ). If the result is greater than the initial -2 log likehood value of the -2 late likehood log, there will be a decrease in the result, where this decrease indicates that the hypothesized model is fit or corresponding to the data. The test results can be seen in the following table: 
UMGCINMATIC : $1^{\text {st }}$ Rethinking Education during Covid-19 Era: Challange and Innovation Volume 1 No 2

Table 4.5

Results of Value Comparison Test Between -2 Early Likehood Logs with -2 Late Likehood Logs

\begin{tabular}{|l|l|}
\hline $\begin{array}{l}-2 \text { Early Likehood Logs } \\
(\text { Block number }=0)\end{array}$ & $\begin{array}{l}-2 \text { Late Likehood Log } \\
(\text { Block number }=1)\end{array}$ \\
\hline 505,852 & 484,611 \\
\hline
\end{tabular}

Source: SPSS 22, Data processed by researchers (2021)

Based on table 4.5 shows that the value of -2 log likehood initial (Block number $=0$ ) amounted to 505,852 and the value of -2 log likehood final (Block number $=$ 1) amounted to 484,611 . This illustrates that the value of -2 log likehood decreased so it can be said that the hypothesized model has been fit or in accordance with the data.

\subsection{Regression Coefficient}

The coefficient of determination can be known through the Nagelkerke $R$ Square value which serves to find out how much variability of independent variables is able to explain the variability of dependent variables. The rest can be explained by other variables outside of the study model.

The test results can be seen in the following table:

Table 4. 6

Determination Coefficient Test Results (Nagelkerke R Square)

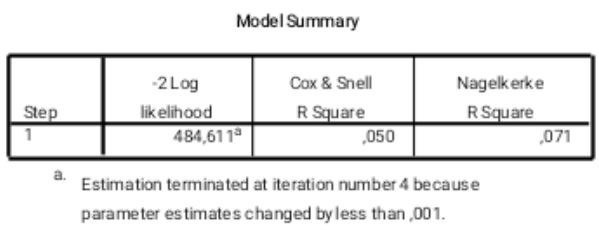

Source: SPSS 22, Data processed by researchers (2021)

Based on table 4. 6 it is known that the coefficient of determination (Nagelkerke $R$ Square) is 0.071 or equal to $7.1 \%$. This suggests that the variability of independent variables capable of explaining the variability of dependent variables in the study was only $7.1 \%$. While $92.9 \%$ was explained by other variables outside the study model.

\subsection{Omnibus Test Of Model Coefficient}

This study aims to find out whether independent variables are simultaneously 
UMGCINMATIC : $1^{\text {st }}$ Rethinking Education during Covid-19 Era: Challange and Innovation Volume 1 No 2

able to influence dependent variables. Here are the results of the Omnibus Test of Model Coefficients:

Table 4.7

Omnibus Test Of Model Coefficient Results

Omnibus Tests of Model Coefficients

\begin{tabular}{|c|c|c|c|c|}
\hline & & Chisquare & df & Sig. \\
\hline \multirow[t]{3}{*}{ Step 1} & Step & 21,240 & $\overline{4}$ & 000 \\
\hline & Block & 21,240 & 4 & 000 \\
\hline & Model & 21,240 & 4 & .000 \\
\hline
\end{tabular}

Source: SPSS 22, Data processed by researchers (2021)

Based on table 4.7 it is known that the value of Chi-square $=21,240$ and the degree of freedom $=4$. The significance level of 0.000 which is this value is less than 0.10 . This shows that the variable leverage, profitability, size of the company and kap reputation affect the timeliness of delivery of financial statements.

\subsection{Logistic Regression Analysis}

This study uses logistic regression analysis because dependent variables are dummy variables i.e. category variables (non-metric) and measured using a nominal scale. Logistic regression analysis is used to determine the extent of the effect of independent variables on dependent variables partially using the wald test. The logistic regression model formed can be seen in the following table:

Table 4.8

Variables in the Equation Test Results

Variables in the Equation

\begin{tabular}{|c|c|c|c|c|c|c|c|}
\hline & & $B$ & SE & Wald & df & $s q$ & Exp(B) \\
\hline \multirow{5}{*}{$\begin{array}{l}\text { Segep } \\
1\end{array}$} & $\overline{\mathrm{X} 1}$ & $; 045$ & .038 & 1,383 & 1 & .240 & .956 \\
\hline & $x_{2}$ & .048 & .235 & ,043 & 1 & .836 & 1,050 \\
\hline & $x_{3}$ & .310 & .080 & 15.117 & 1 & .000 & 1.364 \\
\hline & $x_{4}$ & $; 048$ & .102 & .223 & 1 & .637 & .953 \\
\hline & Constamt & $-7,753$ & 2,181 & 12,633 & 1 & .000 & .000 \\
\hline
\end{tabular}

Source: SPSS 22, Data processed by researchers (2021)

Based on table 4.8 of the logistic regression model formed with the following equations:

$\operatorname{Ln} p /(1-p)(E T R)=-7,753-0.045+0.048+0,310-0.048$ 
UMGCINMATIC : $1^{\text {st }}$ Rethinking Education during Covid-19 Era: Challange and Innovation Volume 1 No 2

Based on the above equation, it can be explained as follows:

1. Leverage variable $(\mathrm{X} 1)$ has a coefficient value of -0.045 , the wald test of 1.383 with a significance level of $0.240>0.05$ then $\mathrm{H} 1$ is rejected. This shows that leverage has no effect on the timeliness of the delivery of financial statements.

2. The profitability variable $(\mathrm{X} 2)$ has a coefficient value of 0.048 , the wald test of 0.043 with a significance level of $0.836>0.05$ then $\mathrm{H} 2$ is rejected. This shows that profitability has no effect on the timeliness of the delivery of financial statements.

3. The company size variable (X3) has a coefficient value of 0.080 , the wald test of 15.117 with a significance level of $0.000<0.05$ then $\mathrm{H} 3$ is accepted. This shows that the size of the company has an effect on the timeliness of the delivery of financial statements.

4. Kap (X4) reputation variable has a coefficient value of -0.048 , the wald test of 0.223 with a significance level of $0.637>0.05$ then $\mathrm{H} 4$ is rejected. This shows that kap's reputation has no effect on the timeliness of the delivery of financial statements.

\section{CONCLUSION}

Based on the description from the beginning to the end of the discussion, the following conclusions were obtained:

1. Leverage variables have no effect on the timeliness of the delivery of financial statements.

2. Profitability variables have no effect on the timeliness of the delivery of financial statements.

3. Company size variables affect the timeliness of the delivery of financial statements.

5. Kap reputation variables have no effect on the timeliness of the delivery of financial statements.

\section{REFERENCES}

Amin Widjaja Tunggal. 2012. Internal Auditing, Edisi Lima. Yogyakarta: BPFE

Astuti, C. D. (2019). Faktor Faktor Yang Berpengaruh Terhadap Ketepatan Waktu Pelaporan Keuangan. Jurnal Informasi, Perpajakan, Akuntansi, Dan Keuangan Publik, 2(1), 27

Budiyanto, S., \& Aditya, E. M. (2015). Faktor-Faktor Yang Memengaruhi Ketepatan Waktu Pelaporan Keuangan: Studi Empiris Perusahaan Food and Beverages Periode 20102012. Jurnal Fokus Ekonomi, 10(1), 77-87.

Brealey, et. al. (2007). Dasar-dasar Manajemen Keuangan. Jakarta: Erlangga.

Brigham, E.F. dan J.F. Houston, 2010. Manajemen Keuangan, Edisi 8. Jakarta: Erlangga.

Connelly, B. L., Certo, S. T., Ireland, R. I. and Reutzel, C. R. (2011). Signaling theory: a review and assessment, Journal of management, 37(1), 39-67. 
UMGCINMATIC : $1^{\text {st }}$ Rethinking Education during Covid-19 Era: Challange and Innovation Volume 1 No 2

Fahmi, Irfan. 2014. Analisis Laporan Keuangan. Cetakan ke-2. Bandung: Alfabeta

Felicyta Fabiolla, N. B. (2019). Faktor-Faktor yang Mempengaruhi Ketepatan Waktu Penyampaian Laporan Keuangan di BEI Periode 2015-2017. Jurnal Multiparadigma Akuntansi, 1(3), 721-729.

Firdaus, Y. D. M., Amin, M., \& Junaidi. (2018). Faktor-faktor Yang Mempengaruhi Ketepatan Waktu Pelaporan Keuangan. Jurnal Akuntansi. 07(10), 119-131.

Ghazali, Imam. 2018. Aplikasi Analisis Multivariate dengan Program SPSS. Semarang: Badan Penerbit Universitas Diponegoro.

Hendratno, Z. R. A. Q. (2019). Faktor-Faktor Yang Memepengaruhi Ketepatan Waktu Penyampaian Laporan Keuangan. Jurnal Multiparadigma Akuntansi. 3(1), 1-15.

Hilmi, Utari dan Syaiful Ali. 2008. "Analisis Faktor-Faktor Yang Memepengaruhi Ketepatan Waktu Penyampaian Laporan Keuangan (Studi Empiris pada Perusahaan-perusahaan yang Terdaftar di BEJ)". Periode 2004-2006. Jurnal Akuntansi Keuangan. Vol 13, 1-17

Ifada, L. M. 2009. Faktor-faktor Yang Mempengaruhi Ketepatan Waktu Pelaporan Keuangan (Studi Kasus Perusahaan Manufaktur Di BEJ). Jurnal Akuntansi Indonesia 5(1): $43-56$ Ikatan Akuntan Indonesia. (2015). Penyajian Laporan Keuangan. PSAK No.1, (1), Jakarta. Jaori, Mario Kristopp, M. (2018). Analisis Faktor-faktor yang Berpengaruh terhadap Pelaporan Keuangan. Jurnal Akuntansi Indonesia, 7(2), 1-15.

Kadir, Abdul. (2011). "Faktor-faktor Yang Berpengaruh Terhadap Ketepatan Waktu Pelaporan Keuangan Studi Empiris Pada Perusahaan Manufaktur Di Bursa Efek Jakarta. Jurnal Manajemen dan Akuntansi. Vol. 12. No.1.Pp.1-12

Kasmir. 2009. Analisis Laporan Keuangan. Jakarta: PT. Raja Grafindo Persada

Kuswanto, H \& Sodikin (2013). Faktor-Faktor Yang Mempengaruhi Ketepatan Waktu Penyampaian Laporan Keuangan Ke Publik (Studi Empiris Pada Perusahaan Manufaktur Yang Terdaftar Di Bursa Efek Indonesia Periode 2010-2013) Jurnal Akuntansi dan Keuangan. Vol 10. No 5

Libby, Robert, dkk, 2008. Akuntansi Keuangan, Edisi Kelima, Yogyakarta:Penerbit Andi.

Mareta, S. (2015). Analisis Faktor-Faktor Yang Mempengaruhi Timeliness Publikasi Laporan Keuangan Periode 2009-2010 (Studi Empiris Pada Bursa Efek Indonesia), Jurnal Akuntansi, Vol XIX, No. 01, 93-108.

Nurmiati. (2016). Faktor-Faktor yang Mempengaruhi Ketepatan Waktu Pelaporan Keuangan Nurmiati Fakultas Ekonomi Dan Bisnis Universitas Mulawarman, Indonesia. Jurnal Ekonomi Dan Manajemen, Vol 13(2), 1-17.

Owusu-Ansah, S., 2000. "Timeliness of Corporate Reporting in Emerging Capital Markets: Empirical Evidence from Zimbabwe Stock Exchange". Journal Accounting and Business Research. Summer: pp. 243-254

Pradipta, D. N., \& Suryono, B. (2017). Analisis Faktor-Faktor Yang Mempengaruhi Ketepatan Waktu. Jurnal IImu Dan Riset Akuntansi, vol 6, 1-17.

Rachmawati, Sistya. (2008). Pengaruh Faktor Internal dan Eksternal Terhadap Audit Delay dan Timeliness. Jurnal Akuntansi dan Keuangan. Vol 10. No 1

Respati, Novita Weningtyas. 2004. FaktorFaktor yang Berpengaruh Terhadap 
UMGCINMATIC : $1^{\text {st }}$ Rethinking Education during Covid-19 Era: Challange and Innovation Volume 1 No 2

Ketepatan Waktu Pelaporan Keuangan: Studi Empiris di Bursa Efek Jakarta. Jurnal Manajemen Akuntansi dan Sistem Informasi (Maksi). Vol 4.Hal 67-81

Rudyawan, Arry P. dan I.D. Nyoman Badera. 2009. Opini Audit Going Concern: Kajian Berdasarkan Model Prediksi Kebangkrutan, PertumbuhanPerusahaan, Leverage dan Reputasi Auditor . Jurnal Akuntansi dan Bisnis, Vol. 4. No. 2. Juli. Hal. 129-139

Sanjaya, I. M. D. M., \& Wirawati, N. G. P. (2016). Analisis Faktor-Faktor Yang Mempengaruhi Ketepatan Waktu Pelaporan Keuangan Pada Perusahaan Manufaktur Yang Terdaftar Di BEl. E-Jurnal Akuntansi Universitas Udayana,15(1), 17-26.

Septriana, I. 2010. Analisis Faktor - Faktor yang Berpengaruh Terhadap Ketepatan Waktu Pelaporan Keuangan Perusahaan BUMN di Indonesia. Jurnal Multiparadigma Akuntansi vol 2, 10-21..

Srimindarti, C. (2008). Ketepatan Waktu Pelaporan Keuangan Fakultas Ekonomi Universitas Stikubank Semarang. Jurnal IImiah Akuntansi Dan Bisnis, 7(1), 14-21.

Saleh (2004). Studi Empiris Ketepatan Waktu Pelaporan Keuangan Perusahaan Manufaktur Di Bursa Efek Jakarta, Jurnal Multiparadigma Akuntansi Vol. 13, pp. 66-80.

Santoso, Singgih. 2000. Buku Latihan SPSS Statistik Parametrik. Jakarta: Elex Media Computindo

Sugiyono. 2016. Metode Penelitian Pendidikan. Cetakan 11. Bandung: AlfaBeta.

Suharli, M., \& Rachpriliani, A. (2006).. Studi Empiris Faktor - Faktor yang Berpengaruh Terhadap Ketepatan Waktu Pelaporan Keuangan. Jurnal Akuntansi. 8(1), 34-55.

Suprapti, R. (2015). Pengaruh Financial Leverage, Profitabilitas, Ukuran Perusahaan dan Kualitas Auditor Terhadap Ketepatan waktu Pelaporan Keuangan (Pada Perusahaan Manufaktur yang Terdaftar di Bursa Efek Indonesia Periode 2011-2015). Jurnal Universitas PGRI Yogyakarta, 1-10.

Suryanto, J., \& Pahala, I. (2016). Analisa Faktor - Faktor Yang Berpengaruh Terhadap Ketepatan Waktu Pelaporan Keuangan (Studi Empiris Pada Perusahaan Otomotif Dan Komponen Dan Telekomunikasi Yang Terdaftar Di Bursa Efek Indonesia). Jurnal Wahana Akuntansi, 11(2), 1.

Tyler.T (1990). Why people obey the law. Yale university Press1-33

Undang-Undang RI Nomor 21 Tahun 2011 Tentang Otoritas Jasa Keuangan.

Undang-Undang RI Nomor 20 Tahun 2008 Tentang Usaha Mikro, Kecil dan Menengah

www.idx.co.id

www.SahamOk.com 